\title{
Studies on the Effect of Plant Growth Regulators and Micronutrients on Okra (Abelmoschus esculentus L) cv. Parbhani Kranti
}

\author{
Ajay Kumawat ${ }^{1 *}$, N.K. Gupta ${ }^{1}$, Nimisha Raj Jain ${ }^{1}$ and Shambhu Nayama ${ }^{2}$ \\ ${ }^{1}$ Department of Vegetable Science, College of Agriculture, Indore-452 001, \\ Madhya Pradesh, India \\ ${ }^{2}$ Department of Plantation, spices, Medicinal and Aromatic crops, College of Horticulture, \\ Mandsaur-458 001, Madhya Pradesh, India \\ *Corresponding author
}

\section{A B S T R A C T}

Keywords

Randomized Block

Design, Growth

regulators,

Micronutrients,

Treatments etc.

Article Info

Accepted:

22 January 2019

Available Online:

10 February 2019
The experiment detail for the present investigation was comprised of 13 treatments in Randomized Block Design with three replication, to record morphological, phonological, yield attributes and economics. The growth regulators and micronutrient significantly improved the plant height of okra. The maximum plant height was recorded when sprayed NAA @ 20 ppm. The higher number of leaves and length of internodes were recorded at NAA @ 40 ppm. Higher numbers of branches, higher length of internodes were recorded in foliar spray of cycocel@1000ppm. The foliar spray of growth regulators and micronutrient was recorded in significant improvement in leaf area on okra. The days taken to first flowering differed significantly the different treatment. The number of flower bud, the fruit length, fruit width, fruit per plant, fruit yield per plot, benefit cost ratio and fruit weight differed significantly in different treatment combination.

\section{Introduction}

Okra popularly Known as 'Bhindi' Okra [Abelmoschus esculentus (L.) Moench] belongs to the family Malvaceae having chromosome no. $2 \mathrm{n}=130$ has captured a prominent position among vegetables. Okra one of the important summer and rainy season vegetable crops cultivated in various states in India. It is widely cultivated in plains of the India with acreage 5.07 Million ha and production 58.5 million tones and11.5 tones productivity. In Madhya Pradesh Okra is grown in 2.8 million ha area with production of 32.8 million tones and 11.7 tones productivity (Anonymous, 2016). It requires long and warm growing season and is susceptible to frost. The optimum day temperature for its well growth is between $25^{\circ} \mathrm{C}$ to $40^{\circ} \mathrm{C}$ and that of night is over $22^{\circ} \mathrm{C}$. Okra seed do not germinate when temperature is below $29^{\circ} \mathrm{C}$. It is a source of protein, vitamins $\mathrm{C}$ and $\mathrm{A}$, iron and calcium and dietary fiber. Okra mucilage is suitable for medicinal and industrial applications. It has medically found application as a plasma 
replacement or blood volume expander. The presence of traces of iodine in the pod of okra makes it a good remedy for goitre. After fruiting, the stalks are generally allowed to go waste or used as fuel. Sometimes, processing of okra involves blanching, which is a heat treatment, given to vegetables to limit. Its fruit are rich in vitamin-A $(88 \mu / 100 \mathrm{~g})$, vitamin-C (13 $\mathrm{mg} / 100 \mathrm{~g}$ ), calcium (66 mg/100g), potassium $(103 \mathrm{mg} / 100 \mathrm{~g}$ ) and other minerals (Aykroyd, 1963). It is a tropical to sub-tropical crop and is sensitive to frost, low temperature, water logging and drought conditions, and the cultivars from different countries have adapted certain distinguishing characteristics specific to the country to which they belong Siemonsma, (1982).

\section{Material and Methods}

The land topography of the experimental site was almost uniform with an adequate surface drainage. The internal drainage of the experimental site is medium. In order to get good tilth of the soil for sowing, one cross cultivation was done by tractor drawn cultivator followed by two harrowing before sowing of seed. The first irrigation was given immediately after sowing to ensure proper germination. There after there was no need of irrigation due to time to time rains which provided sufficient moisture for proper growth and development of standing crop. A dose of $150 \mathrm{~kg} \mathrm{~N}, 100 \mathrm{~kg}_{2} \mathrm{O}_{5}$ and $100 \mathrm{~kg} \mathrm{~K}_{2} \mathrm{O} /$ ha along with 20 tones FYM/ha was applied. One third nitrogen and entire quantity of $\mathrm{P}, \mathrm{K}$ and FYM was applied prior to sowing as basal dose. Remaining dose of nitrogen was applied in two splits at 30 and 60 days after sowing. The crop was sprayed with Imidacloprid $0.5 \%$ to control insect-pest and drenching of Dithane M-45 $0.2 \%$ to control diseases. The data recorded on various parameters such as morphological parameters like Plant height, Leaf area, Number of branches per plant, Number of internodes and length, Number of leaves per plant. Phonological parameters like Number of flower bud and fruits, Days taken to first picking Days to first flowering are recorded. Yield parameters like Fruit length, Fruit diameter, Fruit weight, Fruit yield per plant, Fruit yield per plot and Benefit cost ratio.

\section{Results and Discussion}

The higher plant height was observed in the treatment $\mathrm{T}_{1}$ NAA @20 ppm followed by Feso4 $(0.25 \%)$ while minimum plant height was recorded in $\mathrm{T}_{13}$ control (water spray). The variation of plant height was due to different concentration of PGR and Micronutrients. The significant result found that the application of growth promotive substances increased the plant height this might be due to rapid increase in cell division and cell elongation in the shoot apex. These results are in accordance with the findings of Maharaj et al., (2015). The maximum number of leaves was recorded in the treatment $\mathrm{T}_{4}$ NAA @ $40 \mathrm{ppm}$ followed by Znso4 (0.25\%), The increased number of leaves in these treatments might be due to rapid increase in cell division and cell elongation. This result is in agreement with the result found by Kokare et al., (2013). The maximum number of branches was recorded in the treatment $\mathrm{T}_{8}$ (Cycocel @1000 ppm) followed by $\mathrm{FeSO}_{4}(0.25 \%)$ while minimum was recorded in the treatment $T_{13}$ Control (water spray). The growth retardant chemical cycocel was effective in suppressing apical dominance, thereby promoting the growth of axillary buds into new shoots. The results are in agreement with the result found by Bhagure et al., (2013). Similarly, the micronutrients have been found to increase number of branches significantly. The higher number of internodes was recorded in the treatment $\mathrm{T}_{8}$ (Cycocel @ $1000 \mathrm{ppm}$ ) followed by $\mathrm{FeSO}_{4}(0.25 \%)$ while minimum was recorded in the treatment $T_{13}$ Control. Cycocel reduced intermodal length by restricting the cell division hence, it increased the number of internodes Bhagure et al., (2013) reported that the significant result received by application of (Cycocel @750 ppm and 1000ppm) (Table 1-5). 
Table.1 Effect of different treatments on Plant height $(\mathrm{cm})$ and number of branches at various intervals of the crop stages

\begin{tabular}{|cccccccccc|}
\hline & & \multicolumn{9}{c}{ Plant height $(\mathbf{c m})$} & \multicolumn{3}{c|}{ Number of branches } \\
\hline Treatment & 15 DAS & $\mathbf{3 0}$ DAS & $\mathbf{4 5}$ DAS & $\mathbf{6 0}$ DAS & $\mathbf{7 5}$ DAS & Mean & 60 DAS & 75 DAS & Mean \\
\hline T1 & 13.20 & 25.83 & 32.50 & 35.00 & 36.83 & 28.67 & 1.20 & 1.33 & 1.27 \\
\hline T2 & 9.97 & 20.60 & 24.90 & 28.97 & 31.27 & 23.14 & 1.27 & 1.40 & 1.33 \\
\hline T3 & 10.63 & 20.23 & 25.80 & 29.67 & 30.03 & 23.27 & 1.10 & 1.27 & 1.18 \\
\hline T4 & 12.30 & 22.53 & 28.37 & 31.37 & 33.57 & 25.63 & 1.07 & 1.17 & 1.12 \\
\hline T5 & 10.80 & 20.57 & 25.40 & 29.60 & 30.83 & 23.44 & 1.20 & 1.53 & 1.37 \\
\hline T6 & 11.30 & 21.87 & 26.43 & 30.80 & 32.73 & 24.63 & 1.07 & 1.33 & 1.20 \\
\hline T7 & 10.73 & 19.90 & 25.07 & 29.00 & 30.70 & 23.08 & 1.27 & 1.5 & 1.43 \\
\hline T8 & 10.77 & 20.73 & 25.50 & 28.63 & 30.93 & 23.31 & 1.47 & 2.2 & 1.83 \\
\hline T9 & 10.33 & 19.60 & 25.63 & 28.93 & 31.07 & 23.11 & 1.27 & 1.47 & 1.37 \\
\hline T10 & 10.73 & 20.83 & 25.43 & 28.70 & 30.70 & 23.28 & 1.43 & 1.7 & 1.56 \\
\hline T11 & 10.87 & 20.33 & 25.23 & 28.73 & $30.63 S$ & 23.16 & 1.43 & 1.63 & 1.53 \\
\hline T12 & 10.83 & 20.20 & 24.97 & 28.37 & 30.17 & 22.91 & 1.43 & 1.60 & 1.51 \\
\hline T13 & 8.93 & 19.33 & 23.00 & 28.63 & 31.23 & 22.23 & 0.33 & 0.40 & 0.37 \\
\hline SE \pm m & $\mathbf{0 . 3 0}$ & $\mathbf{0 . 8 2}$ & $\mathbf{0 . 9 6}$ & $\mathbf{0 . 8 6}$ & $\mathbf{0 . 6 4}$ & $\mathbf{0 . 2 8}$ & $\mathbf{0 . 1 0}$ & $\mathbf{0 . 1 4}$ & $\mathbf{0 . 1 1}$ \\
\hline CD (5\% & $\mathbf{1 . 1 2}$ & $\mathbf{3 . 0 5}$ & $\mathbf{3 . 5 8}$ & $\mathbf{3 . 2 0}$ & $\mathbf{2 . 4 1}$ & $\mathbf{1 . 0 6}$ & $\mathbf{0 . 5 5}$ & $\mathbf{0 . 5 2}$ & $\mathbf{0 . 3 9}$ \\
\hline & & & & & & & & \\
\hline
\end{tabular}


Table.2 Effect of different treatments combination on Number of leaves per plants and number of internodes at various intervals of growth stages

\begin{tabular}{|c|c|c|c|c|c|c|c|c|c|c|c|}
\hline \multirow[b]{2}{*}{$\begin{array}{c}\text { Treatmen } \\
\mathbf{t}\end{array}$} & \multicolumn{5}{|c|}{ Number of leaves } & \multicolumn{6}{|c|}{ Number of internodes } \\
\hline & 15 DAS & 30 DAS & 45 DAS & 60 DAS & 75 DAS & Mean & 30 DAS & 45 DAS & 60 DAS & 75 DAS & Mean \\
\hline T1 & 2.33 & 3.73 & 7.87 & 8.90 & 7.43 & 6.05 & 3.2 & 6.7 & 8.0 & 9.1 & 6.80 \\
\hline $\mathbf{T 2}$ & 2.77 & 3.90 & 8.83 & 10.63 & 8.83 & 6.99 & 2.7 & 6.5 & 8.4 & 9.4 & 6.77 \\
\hline T3 & 1.87 & 3.70 & 8.93 & 9.60 & 7.73 & 6.37 & 3.2 & 6.5 & 8.3 & 9.8 & 7.05 \\
\hline T4 & 3.97 & 6.57 & 11.50 & 15.30 & 11.80 & 9.83 & 3.2 & 7.1 & 8.4 & 9.4 & 7.07 \\
\hline T5 & 2.00 & 4.77 & 8.37 & 9.20 & 7.30 & 6.33 & 3.2 & 6.3 & 8.2 & 9.6 & 6.84 \\
\hline T6 & 3.07 & 4.97 & 9.97 & 12.83 & 9.67 & 8.10 & 3.2 & 6.6 & 8.6 & 9.6 & 6.98 \\
\hline T7 & 2.23 & 3.17 & 8.27 & 9.33 & 7.33 & 6.07 & 3.2 & 6.3 & 8.2 & 9.7 & 7.00 \\
\hline T8 & 2.20 & 3.63 & 8.70 & 8.80 & 7.60 & 6.19 & 3.8 & 6.9 & 9.5 & 10.5 & 7.6 \\
\hline T9 & 2.05 & 3.50 & 8.43 & 8.77 & 7.63 & 6.08 & 3.2 & 6.6 & 8.3 & 9.8 & 7.01 \\
\hline T10 & 2.30 & 3.53 & 7.93 & 9.83 & 7.67 & 6.25 & 3.6 & 6.8 & 8.9 & 10.0 & 7.28 \\
\hline T11 & 2.03 & 3.50 & 8.20 & 9.83 & 7.60 & 6.23 & 2.8 & 6.0 & 8.1 & 9.8 & 6.52 \\
\hline T12 & 2.00 & 5.20 & 8.57 & 9.60 & 7.60 & 6.59 & 3.4 & 6.3 & 9.1 & 9.4 & 6.97 \\
\hline T13 & 1.50 & 3.53 & 6.4 & 7.7 & 7.03 & 5.89 & 2.9 & 5.6 & 6.0 & 6.3 & 5.08 \\
\hline $\mathrm{SE} \pm \mathrm{m}$ & 0.21 & 0.42 & 0.87 & 0.89 & 0.29 & 0.21 & 0.18 & 0.19 & 0.35 & 0.25 & 0.14 \\
\hline CD (5\%) & 0.78 & 1.58 & 2.32 & 3.34 & 1.09 & 0.77 & 0.64 & 0.71 & 1.33 & 0.95 & 0.50 \\
\hline
\end{tabular}


Table.3 Effect of different treatments combination on length of inter nodes per plants, Leaf area $\left(\mathrm{cm}^{2}\right)$ at various intervals of growth stages.
Table.4 Effect of different treatments combinations on the days taken to first flowering, Number of flowers bud and fruits and Days taken to first picking

\begin{tabular}{|c|c|c|c|c|c|c|c|c|c|c|}
\hline \multicolumn{6}{|c|}{ length of internodes (cm) } & \multicolumn{5}{|c|}{ Leaf area $\left(\mathrm{cm}^{2}\right)$} \\
\hline Treatment & 30 & 45 & 60 & & Mean & & & 60 & & Mean \\
\hline & DAS & DAS & DAS & DAS & & DAS & DAS & DAS & DAS & \\
\hline $\mathrm{T} 1$ & 2.5 & 3.1 & 2.9 & 3.2 & 2.93 & 81.1 & 254.9 & 355.5 & 354.0 & 261.36 \\
\hline $\mathrm{T} 2$ & 3.6 & 3.6 & 3.5 & 3.7 & 3.63 & 87.4 & 256.2 & 352.8 & 355.7 & 263.00 \\
\hline $\mathrm{T} 3$ & 3.0 & 3.4 & 3.2 & 3.4 & 3.27 & 86.4 & 257.1 & 356.1 & 351.7 & 262.84 \\
\hline $\mathrm{T} 4$ & 2.3 & 3.0 & 3.0 & 3.0 & 2.86 & 89.0 & 262.3 & 367.4 & 361.1 & 269.96 \\
\hline $\mathrm{T} 5$ & 2.3 & 2.9 & 3.0 & 3.1 & 2.83 & 87.6 & 259.6 & 357.8 & 356.5 & 265.37 \\
\hline T6 & 2.9 & 3.3 & 3.1 & 3.3 & 3.14 & 84.3 & 256.5 & 356.3 & 352.0 & 262.28 \\
\hline $\mathrm{T} 7$ & 1.1 & 3.1 & 2.6 & 3.1 & 2.47 & 86.4 & 255.4 & 355.4 & 352.5 & 262.42 \\
\hline $\mathrm{T} 8$ & 2.7 & 2.7 & 2.9 & 3.0 & 2.82 & 87.4 & 252.0 & 352.3 & 349.3 & 260.25 \\
\hline T9 & 2.7 & 3.1 & 2.9 & 3.1 & 2.97 & 87.2 & 258.6 & 355.6 & 352.2 & 263.39 \\
\hline T10 & 2.7 & 3.2 & 3.0 & 3.0 & 2.98 & 88.1 & 260.1 & 359.8 & 357.7 & 266.43 \\
\hline $\mathrm{T} 11$ & 2.8 & 3.0 & 2.9 & 3.0 & 2.93 & 87.6 & 258.5 & 356.4 & 356.4 & 264.72 \\
\hline $\mathrm{T} 12$ & 2.7 & 3.2 & 2.9 & 3.2 & 3.00 & 86.6 & 256.1 & 355.6 & 351.2 & 262.38 \\
\hline $\mathrm{T} 13$ & 1.1 & 1.6 & 2.3 & 2.9 & 1.98 & 79.4 & 249.5 & 322.4 & 240.1 & 222.86 \\
\hline $\mathrm{SE} \pm \mathrm{m}$ & 0.29 & 0.14 & 0.12 & 0.11 & 0.10 & 0.80 & 0.84 & 0.58 & 28.55 & \\
\hline $\mathrm{CD}(5 \%)$ & 1.13 & 0.52 & 0.48 & 0.42 & 0.39 & 2.97 & 3.13 & 2.15 & 106.55 & \\
\hline
\end{tabular}




\begin{tabular}{|cccccc|}
$\begin{array}{l}\text { S. } \\
\text { No. }\end{array}$ & Treatment & $\begin{array}{l}\text { Days taken to first } \\
\text { flowering (Mean) }\end{array}$ & $\begin{array}{l}\text { No. of flowers } \\
\text { bud (Mean ) }\end{array}$ & $\begin{array}{c}\text { No. of fruit } \\
\text { (Mean ) }\end{array}$ & $\begin{array}{l}\text { Days taken to } \\
\text { first } \\
\text { picking } \\
\text { (Mean) }\end{array}$ \\
\hline 1 & T1 & 36.3 & 19.7 & 15.5 & 43.1 \\
\hline 2 & T2 & 36.8 & 26.8 & 22.1 & 46.3 \\
\hline 3 & T3 & 36.2 & 20.2 & 14.4 & 41.2 \\
\hline 4 & T4 & 37.1 & 18.2 & 14.8 & 47.6 \\
\hline 5 & T5 & 37.0 & 23.2 & 18.4 & 43.4 \\
\hline 6 & T6 & 38.4 & 19.2 & 13.4 & 45.9 \\
\hline 7 & T7 & 35.7 & 17.8 & 13.1 & 43.5 \\
\hline 8 & T8 & 42.5 & 18 & 13.4 & 44.1 \\
\hline 9 & T9 & 38.5 & 18 & 13 & 42.6 \\
\hline 10 & T10 & 39.4 & 18.3 & 13.5 & 44.9 \\
\hline 11 & T11 & 34.3 & 18.5 & 13.6 & 43.8 \\
\hline 12 & T12 & 39.7 & 18.1 & 13.5 & 43.4 \\
\hline 13 & T13 & 32.3 & 14.3 & 9.6 & 40.7 \\
\hline 14 & SE \pm m & $\mathbf{1 . 9 9}$ & $\mathbf{1 . 3 4}$ & $\mathbf{1 . 1 3}$ & $\mathbf{1 . 1 5}$ \\
\hline 15 & CD $(5 \%)$ & $\mathbf{7 . 4 6}$ & $\mathbf{5 . 0 1}$ & $\mathbf{4 . 2 3}$ & $\mathbf{4 . 3 1}$ \\
\hline
\end{tabular}

Table.5 Effect of different treatments combinations on the fruit length $(\mathrm{cm})$, Fruit width $(\mathrm{cm})$, Fruit weight $(\mathrm{g})$, number of fruit per plant, fruit yield per plot $(\mathrm{kg})$, yield $(\mathrm{q} / \mathrm{ha})$, gross return and $\mathrm{B}: \mathrm{C}$ ratio.

\begin{tabular}{|c|c|c|c|c|c|c|c|c|c|}
\hline $\begin{array}{l}\text { S. } \\
\text { No. }\end{array}$ & Treatment & $\begin{array}{l}\text { Fruit } \\
\text { length } \\
\text { (cm) }\end{array}$ & $\begin{array}{l}\text { Fruit } \\
\text { width } \\
\text { (cm) }\end{array}$ & $\begin{array}{l}\text { Fruit } \\
\text { weight } \\
\text { (g) }\end{array}$ & $\begin{array}{l}\text { No. of } \\
\text { fruit } \\
\text { plant }^{-1}\end{array}$ & $\begin{array}{l}\text { Fruit } \\
\text { yield per } \\
\text { plot } \mathbf{( k g})\end{array}$ & $\begin{array}{l}\text { Yield } \\
\text { (q.)/ } \\
\text { hac }\end{array}$ & $\begin{array}{l}\text { Gross } \\
\text { return }\end{array}$ & $\begin{array}{l}\text { B:C } \\
\text { Ratio }\end{array}$ \\
\hline 1 & $\mathrm{~T} 1$ & 14.1 & 4.4 & 14.6 & 12.5 & 4.2 & 42 & 6300 & 2.85 \\
\hline 2 & $\mathrm{~T} 2$ & 13.4 & 4.0 & 14.2 & 14.1 & 4.5 & 43.2 & 6480 & 3.66 \\
\hline 3 & $\mathrm{~T} 3$ & 15.3 & 4.6 & 15.1 & 12.1 & 4.1 & 40.7 & 6105 & 3.08 \\
\hline 4 & $\mathrm{~T} 4$ & 13.8 & 4.2 & 13.4 & 12.6 & 4.1 & 44.8 & 6720 & 3.46 \\
\hline 5 & $\mathrm{~T} 5$ & 14.5 & 4.5 & 14.7 & 13 & 4.3 & 41.7 & 6255 & 3.24 \\
\hline 6 & $\mathrm{~T} 6$ & 13.8 & 4.1 & 12.6 & 11.8 & 4.1 & 38.5 & 5775 & 3.34 \\
\hline 7 & $\mathrm{~T} 7$ & 13.2 & 4.1 & 12.3 & 12 & 4.1 & 41.4 & 6210 & 3.29 \\
\hline 8 & $\mathrm{~T} 8$ & 13.2 & 4.2 & 12.3 & 11.8 & 4.1 & 40.5 & 6075 & 3.18 \\
\hline 9 & $\mathrm{~T} 9$ & 13.06 & 4.0 & 11.9 & 10.4 & 4 & 39.9 & 5985 & 3.19 \\
\hline 10 & $\mathrm{~T} 10$ & 11.5 & 4.1 & 11.4 & 10.5 & 4 & 39.6 & 5940 & 3.07 \\
\hline 11 & $\mathrm{~T} 11$ & 13.6 & 3.9 & 10.2 & 12.1 & 3.9 & 41.6 & 6240 & 3.02 \\
\hline 12 & $\mathrm{~T} 12$ & 11.2 & 3.8 & 9.8 & 9.6 & 3.9 & 42.4 & 6360 & 3.28 \\
\hline 13 & $\mathrm{~T} 13$ & 10.2 & 3.2 & 9.1 & 8.5 & 3.2 & 32 & 4800 & 2.69 \\
\hline 14 & $\mathrm{SE} \pm \mathrm{m}$ & $\mathbf{0 . 3 5}$ & $\mathbf{0 . 1 3}$ & $\mathbf{0 . 4 1}$ & $\mathbf{0 . 4 8}$ & $\mathbf{0 . 2}$ & & & \\
\hline 15 & $\mathrm{CD}(5 \%)$ & $\mathbf{1 . 3 1}$ & $\mathbf{0 . 5 0}$ & $\mathbf{1 . 5}$ & $\mathbf{1 . 8}$ & $\mathbf{0 . 7 4}$ & & & \\
\hline
\end{tabular}


The higher leaf area was recorded in the treatment $\mathrm{T}_{4}$ (NAA $40 \mathrm{ppm}$ ) followed by Znso4 $(0.25 \%)$, similarly due to, use of micronutrients significantly higher leaf area was recorded under soil application of $\mathrm{ZnSo} 47.5 \mathrm{~kg} / \mathrm{ha}$. The cycocel might have induced synthesis of flowering hormone affecting early flowering. Similar result was reported by Rajputet et al., (2011) in cycocel @ 100,200,300 ppm was sprayed. The days taken to first flowering was significantly increased in $\mathrm{T}_{8}$ (Cycocel @ 1000 ppm) followed by Feso4 (0.25\%) while minimum was recorded in the treatment $\mathrm{T}_{13}$ Control. The cycocel might have induced synthesis of flowering hormone affecting early flowering. Similar result was reported by Rajput et al., (2011) in cycocel @ 100,200,300 ppm was sprayed. The data recorded on the days taken to first picking under the influence of plant growth regulators and micronutrients combinations. The increase in number of pickings might be due to early flowering and more number of nodes which might have accounted for more pods at less intervals of time. Similar result also found by Parsad and Srihari (2008) with Cycocel in Okra. The higher number of flower bud and pods was reported in $\mathrm{T}_{2}$ (NAA @ 40 ppm) followed by FeSO4 0.25\%. However, the minimum number of flower bud and pods was recorded in $\mathrm{T}_{13}$ (control). The increase number of flower bud and fruits application of growth regulators which are capable of redistribution of dry matter in the plant thereby bringing about an improvement in yield which depends not only on the accumulation of photosynthesis during crop growth and development but also on its partitioning in the number of flowers due to the acceleration of axillary buds into new shoots providing extra sites for more flower. Similar result was observed by Surendra et al., (2006.The higher fruit length, fruit diameter and fruit weight). The increase in the size of fruit i.e. length and diameter were recorded in $\mathrm{T}_{3}$ (NAA@ 20 ppm) followed by $\mathrm{MgSO}_{4} 0.5 \%$ while lower was observed under $\mathrm{T}_{13}$ control (water spray) might be a result of cell enlargement and cell elongation, which is caused by the supply of growth regulators within the plants similar results were reported by Sanodiya et al. (2017). The higher fruit length, width, diameter associated with soil application of boric acid @6\%on chili. The result has been disagreed found by Devi et al., (2013). The increase in fruit yield higher in the $T_{2}$
(NAA@ 40 ppm) followed by FeSO4 0.25\% while the minimum fruit per plant and yield per plot was observed in $\mathrm{T}_{13}$ (control). The increase in fruit yield could be attributed to betterment in the growth parameters. The results obtained may be explained on the basis that the treated plants remained physiologically more active, resulting in more number of flowers and more number of pods. Similar use of micronutrients has been found significantly higher number of per plot has been found by Surendra et al., (2006) by the application of NAA @ 20 and 40 ppm among $\mathrm{FeSO}_{4} 0.5 \%$. The higher B: $\mathrm{C}$ ratio obtained in $\left(\mathrm{T}_{2}\right.$ NA A @ 40 ppm followed by $\mathrm{FeSO}_{4} 0.25 \%$ ). Similar results were observed by Surendra et al., (2005). From the point of economics, it is thus inferred that the use of PGR foliar spray at 20 and 40 days after sowing could be recommended for increasing both unit productivity and also net returns. Similar use of micronutrients has been found to have higher $\mathrm{B}$ : $\mathrm{C}$ ratio by the application of $\mathrm{FeSO}_{4} 0.5 \% 60 \mathrm{DAS}$ after sowing.

\section{References}

Anonymous (2016) Statistical status report, National Horticulture Board, Gurgaon (Haryana). India.

Aykroyb, W.R. (1963). The nutritive value of Indian foods and Planning of satisfactory diets, $I M C R, \mathrm{~S}$ pecial Report Series No- 42

Bhagure, Y.L. and, growth and yieldof okra [Abelmoschus esculentus (L.) Moench] var. ParbhaniKranti. The Asian J. Hort., 8(2): 399-402.

Devi, C.P., Durvesh K. Singh and S.K. Jain. (2013). Effect of foliar feeding of micronutrients on growth and yield of chilli. Pantnagar Journal of Research 7(1): 105-11

KanhaiyalalSanodiya. Geeta Pandey.; Saklesh. Pranjal Singh Rajput.; and Ajay kumar Verma. (2017). Effect of seed treatment with growth regulator on growth, yield and seed quality parameters of okra. Internatinol journal ofchemical studies 5(5): 23012304

Kokare, R.T. Bhalerao, R.K. prabhu, T., Chavan, S.K., Bansode, A.B; and Kachare G.S. (2006). Effect of plant growth regulators on 
growth, yield, and quality of okra [Abelemoschus esculentus (L.)Moench]. Agri.Sci.Digest, 26(3):7881

Mehraj, H., Taufique, T., Ali, M. R., Sikder, R. K and Jamal Uddin, A. F. M. (2015). Impact of GA3 NAA on Horticultural traits of Abelmoschus esculentus. World Applied Sciences Journal, 33(11):1712-1717.

Prasad PN, Singh SK, Yadava RB, Chaurasia SNS. Effect of GA3 and NAA on growth and yield of tomato. Vegetable Science. 2013; 40(2):195-197.

Rajput, B. S., Singh, A. Patel, P. and Gautam, U. S. (2011). Study of different plant growth retardants on flowering, fruiting, yield and economics of okra (Abelmoschus esculentus). Progressive Hort., 43(1): 166167.

Siemonsmos, J.S. (1982). West Africa Okra. morphological and cytological indication for the existence of a natural amphiploid of Ablemoschus esculantus (L) Moench and A. Manihot (L) Medikus. Euphytica, 31(1): 241-252.

Surendra, P., Nawalagatti C.M., Chetti M.B. and Hiremath S.M. (2006). Effect of plant growth regulators and Micronutrients on yield and yield components Okra Karnataka J. Agri.sci., 19(2): (264-267).

\section{.How to cite this article:}

Ajay Kumawat, N.K. Gupta, Nimisha Raj Jain and Shambhu Nayama. 2019. Studies on the Effect of Plant Growth Regulators and Micronutrients on Okra (Abelmoschus esculentus L.) cv. Parbhani Kranti. Int.J.Curr.Microbiol.App.Sci. 8(01): 3216-3223.

doi: https://doi.org/10.20546/ijcmas.2019.802.376 